\title{
What contribution does the installation of solar water heaters make towards the alleviation of energy poverty in South Africa?
}

\author{
Holle Linnea Wlokas \\ Energy Research Centre, University of Cape Town
}

\begin{abstract}
The South African government has publicized plans to install one million solar water heaters in households throughout South Africa by the year 2014, with the goals of reducing strain on existing electricity resources, mitigating greenhouse gas emissions, creating employment and alleviating poverty. This paper examines two existing solar water heater installation projects with the aim of investigating the social contribution of the installation of solar water heaters in low-income households in South Africa. The Sustainable Urban Livelihoods approach (SULA) was adjusted to provide an analytical framework for the development of suitable indicators of social change in the context of renewable energies and energy poverty. Increases in household capital and the reduction of household vulnerability to shocks, stressors and seasonal variability as the result of solar water heater installation were investigated in projects in low-income housing developments in the cities of Cape Town and Port Elizabeth, South Africa.

Data collected from paired household surveys (before and after installation) in over 600 households and qualitative information (Most Significant Change stories) show that the provision of a constant, cheap source of heated water contributed positively to the alleviation of energy poverty. Household capitals (categorised as Human, Social, Financial, Physical, Natural and Gender capital), including aspects such as health benefits and time and financial savings, were all positively effected by the installation of solar water heaters. In addition, improved energy security greatly reduced household vulnerability to shocks, stressors and seasonal variability. Comparison between the two projects revealed that the geographical setting (climatic conditions in particular), and the approach and strategies adopted by the implementers of the solar water heater installation project, greatly determine the extent to which benefits to the households are realised.
\end{abstract}

Keywords: solar water heater, energy poverty, renewable energy, social contribution, sustainable urban livelihoods, South Africa

\section{Introduction}

Since the Energy Minister, Mrs Peters, announced at the Solar Water Heating Conference in Johannesburg in November 2009 that one million solar water heaters (SWH) would be in place by 2014 (Peters, 2009), installations can be seen throughout the country. Even to the knowledgeable observer can the situation sometimes seem like described in Mrs Peters speech where she said that in one to two years, anyone who comes back from overseas and is surprised by the appearance of the solar geysers, 'they will be asked, have you been on the moon or mars or somewhere that you didn't hear?' (Peters, 2009). When studying the government financed SWH rollout in the low-income residential sector closer, it soon becomes obvious that the rollout of this technology is rather spontaneous and is basically proceeding in the absence of central planning. The number of total installations on lowincome houses is unknown to government (DOE, 2011).

This initiative of the South African government is, however, driven by high expectations for the impact of solar water heating. The technology is supposed to address the country's electricity challenge, mitigate greenhouse gas emissions, create employment and alleviate poverty (Afrane-Okese, 2009). How does solar water heating alleviate poverty? Many papers and reports look at technical and financial aspects of project implementation, such as the suitability of high-pressure systems, the potential emission reductions and achievable carbon revenues through SWH. The impact of solar water heaters on people's livelihoods, their energy 
use and their behaviour regarding water consumption remains largely unexplored. The aim of the South African government's mass SWH roll-out is to contribute to poverty alleviation and yet the positive social contribution of the installation of solar water heaters on low-income households has empirically not been sufficiently tested.

This paper explores the assumption that solar water heaters installed in low-income households increase the household's capital and decreases the vulnerability of the households to poverty. The research supports the discussion around the social benefits of renewable energy, looking at solar water heaters in particular and debates it in the context of appropriate project implementation. Data and information are drawn from household surveys and qualitative research undertaken in two SWH projects implemented in South Africa.

\section{International and local expectations of the social contribution of solar water heating}

Solar water heating is not a new innovation; it has been tested in many countries. South Africa is ranked $35^{\text {th }}$ despite the fact that it has 'annual 24hour global solar radiation average of about 220 $\mathrm{W} / \mathrm{m}^{2}$ ' and 'one of the highest in the world' (Department of Minerals and Energy, 2009).

There was a worldwide operating solar thermal heat capacity of 147 GW in 2007 and yet information about the social benefits of SWH installed in residential houses is not readily available. The Renewable Energy Policy Network for the 21 Century speaks about solar water heating as having the potential to "partially or wholly substitute the use of electricity, LPG, and oil for water heating in areas with sufficient solar radiation' (REN21 Renewable Energy Policy Network, 2005). The financial aspect is found to be the major benefit for households in a SWH pilot project in Zimbabwe'from an individual household accounting perspective, SWH use saves about [US] \$1000 in discounted water heating costs over a 15-year period' (Batidzirai, 2009). Despite the long pay-back period for low-income households, definite benefits of the installed technology are expenditure savings for fuel, independence from energy prices and reduction of external costs associated with air pollution from wood combustion, paraffin poisoning, fires and burns and wood collection (Batidzirai, 2009).

Manyaapelo's (2000) research around consumer responses on a mobile solar water heating system in South Africa was based on similar conceptual ideas. Manyaapelo describes a chain of associated risks with the use of fuels for heating water in a lowincome household which could be mitigated through the usage of a SWH.

Warm water is essential for the preparation of many staple foods, and even more relevant to proper hygiene (..) When fuels are burnt inside the home, air quality and safety deteriorate. Fires are a frequent event in such households, as is paraffin poisoning. Smoke causes respiratory and eye, nose and throat ailments. The carbon monoxide from poorly designed and serviced stoves deteriorates brain functions, impacting productivity, and the ability to learn.

The social contribution of 100 solar water heaters installed in low-income households in Durban was researched with a baseline and a follow up household survey. The results are

- The majority of households stated that they use less fuel in general than before the installation.

- Fewer households use wood and LPG and more households use electricity and paraffin for water heating.

- The financial savings due to the SWH are estimated by $70 \%$ of the respondents to be between R50 and R100 per month.

- Almost every respondent of the follow up survey would recommend the installation to friends (Cawood, 2004).

Environmental and economic benefits from SWH are outstanding, but social benefits linked to the reduction of the fossil fuel usage of households are also possible. Han et al. (2009) find that SWH allows the inhabitants of the Chinese city Zhejiang to live more healthy lives - fuel costs are lower, indoor air quality is improved and electric shocks from electric water heaters are less frequent. Additional observations from the All-China Women's Federation show that laundry and dish washing with cold water is the main cause for the extremely common incidence of rheumatoid arthritis suffering, particularly among women. 'SWH introduction increases the availability and use of hot water and, thus, reduces the prevalence of rheumatoid arthritis' (Han, 2010).

Taking the information from these publications it seems that the benefits of SWH installations on lowincome households are: fuel expenditure savings, improved health (respiratory, orthopaedic and rheumatic) and reduced risk associated with fuel usage (electric shocks, paraffin poisoning, burns and fires). A further benefit is highlighted by Mokwena (2009) as she concludes in her report about South African municipal responses to climate change that in the case of solar water heater installations for low-income housing it has been possible to strike this policy balance between addressing the immediate needs of citizens and addressing climate change through an integrated policy approach' (Mokwena, 2009).

As well as academic literature and project reports, the Project Design Documents (PDD) and Program of Activities (PoA) Design Document of Clean Development Mechanism projects have been 
reviewed. The most common social benefit mentioned in them is the improvement of indoor air quality (Tunisia, 2009) (Kuyasa, 2005). A project in Vietnam also talks about the reduced risk of electric shocks as experienced by the Chinese (Vietnam, 2009).

Most of the benefits mentioned above are also expressed in the project documentation of the two case study projects - the Kuyasa CDM Project and the Zanemvula SWH Project. The Kuyasa CDM Project has a strong focus on the social benefits of the project intervention and has even done a preinstallation study which concluded that job creation through installation and maintenance of the technology, annual energy expenditure savings around R625 per household and improved health are possible outcomes of the project (Kuyasa, 2005). This project was the first project from Africa to be registered under the Clean Development Mechanism and was awarded with the Gold Standard Award for carbon projects with a particular focus on sustainable development soon after its inception. The pre-installation assessment finds that the ten installed pilot SWH 'had a substantial impact on the livelihoods of the ten households' (Cousins, 2003). The technology was found to be 'admired and appreciated by the households' and 'significant energy savings' through the usage of pre-heated water from the SWHs were expected in future.

The Nelson Mandela Bay Municipality Solar Water Heater Pilot Project (referred to as the Zanemvula SWH Project) is aiming to improve the quality of life by providing a free source of hot water to households' (Van der Merwe, 2009). In order to qualify this improvement the author was contracted to assess the project. The results of this research and the surveys conducted in Kuyasa will be tested in this paper on the basis of the following described analytical framework.

\section{Analytical framework: Sustainable urban livelihoods approach}

The Sustainable Urban Livelihoods Approach was chosen as the tool for the analysis in this paper and an adjusted version creates the basis for indicators for testing the hypotheses about the contribution of $\mathrm{SWH}$. The results of the application of two important elements of the SULA to the two case study projects stand in the centre of this paper as they are used as questions in the empirical work. In the following, the household capitals and the vulnerability context will be applied to solar water heater interventions and their benefits for low- income households.

The central hypothesis in this paper is that solar water heaters installed in low-income households increase the household's capital and decrease vulnerability. The terms household capital and vulnerability create the substance for the vague term social contribution. The research question is subsequently: What is the social contribution, in terms of household capital and vulnerability, from the installation of solar water heaters? What is the potential of this renewable energy technology to alleviate energy poverty?

\subsection{Linkages between household's assets and solar water heater interventions}

The SULA was applied to the assessment of the provision of solar water heaters in a low-income community. Possible changes and benefits were identified, based on the SULA model and available literature. The SULA further informed the design process of the follow-up questionnaires in the two case study projects. Tables 1 and 2 show the theoretical application of the SULA to the solar water heater intervention. The linkages between the household's assets and solar water heater interventions in an urban context are identified, assuming a South African urban context.

The main linkages identified as 'Natural Capital' are the reduction of greenhouse gas emissions, the substitution of fossil fuels with solar energy, the improvement of indoor air quality and the reduction of deforestation. To fulfil these expectations certain changes have to occur in the households. The heated water from the solar water heater has to be used instead of water heated by other means. According to Winkler and Thorne's theory of suppressed demand (Winkler, 2002) states that low-carbon technology is able to reduce future carbon emissions of a household. Installing solar water heaters in low-income households, which do not have an electric geyser, can substitute the fossil fuel used for heating water manually, but also prevent households from buying an electric geyser once they have the financial means to do so. Electricity demand is suppressed as a result of poverty or lack of infrastructure, and low-carbon technologies which prevent future carbon emissions are valid interventions for reducing global greenhouse gas emissions under the UNFCCC. In the case of Kuyasa, the emission savings achieved through the installation of solar water heaters are calculated to be $1.288 \mathrm{CO}_{2}$ tonnes per household per year (Kuyasa, 2005). Less frequent heating of water and a possible switch from burning wood or charcoal due to increased monetary savings in the households would further lead to improved indoor air quality in houses and a reduction of deforestation.

Social Capital is addressed through community connection and social networks fostered by the project. The social network that has the greatest potential to be influenced by this project is the network created by the common experience of living with a solar water heater. This network is most likely to be fostered by a particularly positive or negative perception of the group of beneficiaries, by 
themselves or by the rest of the community. The survey process and training sessions for the community are also expected to have a positive influence on the relationships between people in the community.

Training, employment, improved health and education are the crucial aspects tackled by SWHs interventions in terms of 'Human Capital'. Training and employment of people from the community where the project is implemented stimulate human capital. SWH may influence the physical and mental health of children and adults through the availability of warm water for baths, improved indoor air quality and decreased depression. School atten- dance may increase because of improved child health and less pressure to collect fuel impacts positively on education. Adults who receive training in renewable energy and solar water heating technology expand their knowledge, gain confidence and perceive SWHs as something of value.

The ownership of new technology and increased material wealth benefits 'Physical Capital'. That the households own the SWHs is crucial.

Increased incomes, income security and reduced expenditures promoted by employment and fuel savings improve 'Financial Capital'. Financial support for the maintenance of the SWH systems and government support through subsidies

Table 1: Linkages between household's assets and solar water heater interventions

\begin{tabular}{|c|c|c|}
\hline Capital assets & Benefits of solar water heater interventions & Indicators for measuring success of intervention \\
\hline \multirow[t]{4}{*}{ Natural capital } & Reduction of greenhouse gas emission & $\begin{array}{l}\text { Usage of SWH water, less heating of water with } \\
\text { stove/electric kettle, suppressed demand theory }\end{array}$ \\
\hline & Solar energy substitute for fossil fuel & $\begin{array}{l}\text { Usage of SWH water, less heating of water with } \\
\text { stove/electric kettle }\end{array}$ \\
\hline & Improvement of indoor air quality & $\begin{array}{l}\text { Fuel change possible through income savings due to } \\
\text { reduced fuel costs for water heating }\end{array}$ \\
\hline & Reduction of deforestation & $\begin{array}{l}\text { Less fuel wood reliance due to improved financial } \\
\text { situation }\end{array}$ \\
\hline Social capital & Foster community connection & $\begin{array}{l}\text { Group of SWH beneficiaries created, surveying helps } \\
\text { people to get to know each other, training sessions } \\
\text { new context for spending time together }\end{array}$ \\
\hline \multirow[t]{7}{*}{ Human capital } & Training & $\begin{array}{l}\text { Training of local people for installation and } \\
\text { maintenance of SWH }\end{array}$ \\
\hline & Employment & Employment of trained and untrained local people \\
\hline & Time savings & Time savings through not heating water manually \\
\hline & Improved health of infants and children & $\begin{array}{l}\text { Warm water for children's bath, improved indoor air } \\
\text { quality }\end{array}$ \\
\hline & Improved mental health of families & $\begin{array}{l}\text { Decreased depression through experiencing SWH as } \\
\text { element which relieves burden of fuel collection and } \\
\text { processing }\end{array}$ \\
\hline & Education & $\begin{array}{l}\text { Through improved health, children might attend } \\
\text { school more often }\end{array}$ \\
\hline & Access to information & $\begin{array}{l}\text { Training for beneficiaries in renewable energy } \\
\text { technology and sustainability }\end{array}$ \\
\hline Physical capital & $\begin{array}{l}\text { New technologies } \\
\text { increased material wealth }\end{array}$ & $\begin{array}{l}\text { SWH has to be in ownership of beneficiary } \\
\text { Labour saving private appliances could be purchased } \\
\text { with saved income }\end{array}$ \\
\hline Financial capital & Financial support in maintenance of SWH & $\begin{array}{l}\text { Incomes through trade of certificates on either } \\
\text { compliance or voluntary carbon market }\end{array}$ \\
\hline \multirow[t]{5}{*}{ Gender capital } & Reduced expenditure & $\begin{array}{l}\text { Reduced fuel costs through reduced need to heat } \\
\text { water, selling of hot water }\end{array}$ \\
\hline & Increased income & $\begin{array}{l}\text { Employment related to installation, maintenance or } \\
\text { training of beneficiaries }\end{array}$ \\
\hline & Income security & $\begin{array}{l}\text { Formal employment for installation, maintenance or } \\
\text { training of beneficiaries }\end{array}$ \\
\hline & $\begin{array}{l}\text { Government support (through subsidies } \\
\text { and similar) }\end{array}$ & $\begin{array}{l}\text { Government support for appliance, installation and } \\
\text { maintenance }\end{array}$ \\
\hline & $\begin{array}{l}\text { Changes benefiting women or men } \\
\text { in particular }\end{array}$ & $\begin{array}{l}\text { Gender specific changes linked to certain tasks } \\
\text { or behaviour of women and men. }\end{array}$ \\
\hline
\end{tabular}


and pro-poor carbon revenue can further contribute to the broadening of the 'Financial Capital' of a household.

The SULA has not been designed to include gender capital, but it has been added to the model here in order to track possible gender specific benefits.

\subsection{Vulnerability context related to $\mathrm{SWH}$ benefits}

The vulnerability context as defined by Chambers (1989) and applied to energy services by Andrew Barnett (2001) is here further extended to solar water heater interventions. The factors influencing the vulnerability of households depend on their local geography, location, seasonality and population density as well as trends in technology and governance practices.

In terms of geography is the amount of solar radiation and the risk of frost possible vulnerable points for households which hope to use hot water regularly? Climatic conditions also influence the need for heated water and possible water shortages in seasons with little or no rainfall which would increase vulnerability. The costs of the technology and the availability of qualified SWH installers and maintainers differ between countries and regions.

Increased costs for supply and maintenance could be a problem in remote areas making electricity saving technologies like SWH dependant on the location of a household or community, whether this is remote or close to an urban centre.

As well as the general climate conditions in which a SWH is expected to function, there are sea- sonal differences which will impact on the need for heated water and the availability of it. Installation and maintenance costs could be higher during the cold and wet seasons.

Social acceptance of new technology is generally expected to spread faster in urban and highly populated areas where there are also governmental initiatives to promote SWHs. Improved solar water heating technology can convince those who have not been satisfied with currently available systems.

Shocks which are specific to living with a SWH are theft and damage of the system. Also power cuts might influence electrified households and force them to temporarily climb down the energy ladder. The falling back onto traditional biomass might be prevented by the provision of heated water from the solar water heater.

\section{Data collection: Background}

The methodological approach of this paper combines quantitative and qualitative research and data. A general analytical framework was created based on existing academic literature and technical project reports. The international experience on the analysis of social issues around solar water heating in low-income communities provided very limited information which was in most cases not well supported by empirical data, but based on assumptions.

In the two case study projects, the Kuyasa CDM Project and the Zanemvula SWH Project, have a baseline and follow up household surveys been conducted. All surveys worked with local, mostly female enumerators and further information was

Table 2: Vulnerability context related to SWH benefits

\begin{tabular}{ll}
\hline Shocks, stresses and season & \\
\hline Geography & Solar radiation levels and frost risk \\
\hline & Costs and availability of SWH and qualified installers \\
\hline Climate determines the need for heated water \\
\hline $\begin{array}{l}\text { Restricted water supply in extremely dry summers when local government releases } \\
\text { water restrictions and stops }\end{array}$ \\
\hline Remoteness adds to the costs of SWH supply and maintenance \\
\hline Seasonality & costs \\
\hline Need for heated water might change with seasons \\
\hline Prends in governance & Installation and maintenance costs might vary with season \\
\hline Availability of heated water might depend on season \\
\hline Sechnological trends & Government decisions on SWH can influence availability, costs etc. \\
\hline Shocks & $\begin{array}{l}\text { Fostering of renewable energy by government can increase acceptance of } \\
\text { technology }\end{array}$ \\
\hline Improved low-cost SWH technology influences acceptance \\
\hline
\end{tabular}


collected through personal observation and communication with stakeholders of the project and from project documents. The SULA is further informed by a Gender Issues Identification and Most Significant Change Stories which have been collected in a written form and on a voluntary basis from the project manager, the counsellor and three of the enumerators who live in the community and worked on the follow-up survey. Additional information is based on observations and personal communications with stakeholders throughout the implementation process of the project.

\subsection{Limitation of the research}

After the data collection had started the Sustainable Livelihoods Approach gradually gained more influence in the work. Because it was not incorporated from the start of the project, or at least the research, a comprehensive application of this approach was not possible.

A further, limiting factor was the quality of the work done by the survey enumerators. Both projects had their own team of local enumerators whose education and communication skills varied considerable. The quality of the completed questionnaires (in total over 3800 ) was not always consistent. Efforts have been made to eliminate errors and inconsistencies in individual questionnaires.

The work in the two communities did not always run smoothly. In Zanemvula, for example, the community prevented the survey from progressing because the community's rules regarding employment procedures had not been respected by the municipality when selecting the enumerators. A toyi-toyi ${ }^{1}$ demonstration forced the project management to review their employment process and employ more enumerators (Smit, 2009). The base- line survey in Kuyasa was interrupted by xenophobic attacks ${ }^{2}$ which forced the survey management to put the survey on hold for some days. These incidents are likely to have influenced the answers given by some households.

Other potential biases may stem from the socioeconomic and cultural background of the researchers and survey managers.

\section{Energy and poverty in Kuyasa and Zanemvula}

According to the Human Development Index, South Africa is placed $129^{\text {th }}$ out of 175 countries. The average life expectancy of South Africans is 51,5 years and in the third quarter of 2009, 24,5\% of the population was unemployed (UNDP, 2009) (Stats SA, 2009). The Energy Development Index places South Africa on rank 38 out of 75 developing countries measuring energy poverty in over 100 countries using per capita commercial energy usage; the proportion of total energy use that is commercial and the share of population with access to electricity for each country by calculating the arithmetic means of the three values for each country.

The latest statistics show that nationally $81.5 \%$ of households are connected to the national electricity grid. In the Western Cape Province, where the Kuyasa CDM project is situated, $96 \%$ of houses are electrified. This is far ahead of the Eastern Cape, where Zanemuula SWH Project is located, where only $70 \%$ of houses have a municipal electricity connection. Most of the houses without electricity are located in rural areas (Visagie, 2008) (Bekker, 2008). The Eastern Cape has a large rural population and is underprivileged in this regard. Countrywide about 2.5 million people (most of

Table 3: Brief overview of the two case study projects

\begin{tabular}{lll}
\hline Name & Kuyasa CDM Project & Zanemvula SWH Project \\
\hline Location & Cape Town & Port Elizabeth \\
\hline Type of project & CDM Project & Voluntary carbon project \\
\hline Size & 2309 households & 1263 households \\
\hline Project owner & City of Cape Town & Nelson Mandela Bay Municipality \\
\hline Project implementer & South African Export Development Fund & Nelson Mandela Bay Municipality \\
\hline Project activities & Solar water heater, insulated ceiling, \\
& compact fluorescent lights and wiring & Solar water heater \\
\hline Survey activities & Social baseline survey conducted in May and & $\begin{array}{l}\text { Social baseline survey conducted in } \\
\text { June 2008, small follow-up done in November } \\
\text { survey done in September 2009, }\end{array}$ \\
& $\begin{array}{l}\text { 2008, big follow-up for June 2009 (not included } \\
\text { in analysis) }\end{array}$ & $\begin{array}{l}\text { big follow-up for April 2010 (not } \\
\text { included in analysis) }\end{array}$ \\
\hline $\begin{array}{l}\text { Further research } \\
\text { State of affairs with }\end{array}$ & Personal communication and observation & $\begin{array}{l}\text { Gender Issue Identification, Most } \\
\text { Significant Change Stories, Personal } \\
\text { communication and observation }\end{array}$ \\
\hline \begin{tabular}{l} 
implementation \\
\hline
\end{tabular} & & $\begin{array}{l}\text { Completed in June 2010 } \\
\end{array}$ \\
\hline
\end{tabular}


them in rural areas) are without (legal) electricity connections and as a result $27.1 \%$ of households cook with wood or paraffin (Stats SA, 2008).

\subsection{The Zanemvula SWH Project}

The Zanemvula SWH Project consists of 1263 government houses that are receiving solar water heating technology. The Zanemvula housing project is located in the low-income settlement of Boysen Park in Port Elizabeth. The Zanemvula community was only established at the beginning of 2008 . Every house that was approved by the government in March 2009 was included in the solar water heater project. The total Zanemvula housing project consists of 3432 houses and around 800 additional self-built shacks. When Zanemvula is mentioned in this paper it refers only to the group of beneficiaries of the SWH project. The project is being paid for by the municipality, and an involvement in the voluntary carbon market is being discussed. The implementation started in March 2009 and was completed in March 2010.

The vulnerability context of households in the Zanemvula community is affected by poverty. Zanemvula is located at the very outskirts of the city of Port Elizabeth, 40 kilometres from the central business district. The only public transport is mini taxis that take up to an hour to travel to the city centre.

There are very few employment opportunities nearby. Major industries are far away and domestic and informal work is scarce. Zanemvula is such a young community that research and poverty assessments have not yet been conducted. The nearby Motherwell community will be used as a reference for poverty as it is much more established and researched. The poverty index in Motherwell is 16.7 according to David Everatt's study (2009) conducted in $2006 .^{3}$ The average poverty index in the eight poorest urban nodes in South Africa was 18.2 in the same year. Urban poverty, as well as rural poverty, has decreased from 1996 to 2006, in urban nodes from 29.2 in 1996 to 18.2 in 2006.

The baseline survey conducted by the author revealed that on average three people were living in each house in Zanemvula. The average family has 1.7 children. In the community of beneficiaries 95 households had a person above the age of 60 years living with them and a total of 55 people with special needs live in Zanemvula. An average of 1.6 people in each household was bringing some kind of income to the household's monthly budget. The most common income sources were government grants and employment.

Before the project started only about $35 \%$ of the houses in Zanemvula were consuming electricity and either their neighbours or the municipality were paid for this service. ${ }^{4}$ Water connections were reported in $31 \%$ of the houses. The most common energy sources for lighting were paraffin $46 \%$ of households) and conventional light bulbs (34\%). Compact fluorescent light bulbs (9\%) and candles (3\%) were also used and multiple sources of lighting were used by nine percent of households. Household heating in winter was reported by only $6 \%$ of the households; paraffin $(8 \%)$ and wood (7\%) being the most common heating fuels. Multiple fuel usage was reported by only one percent of households. For cooking the residents of Zanemvula used mostly paraffin $(69 \%)$ or electricity $(27 \%)$; multiple fuel usage for cooking was the exception - only reported in three percent of the households.

Factors affecting energy usage in Zanemvula are the limited access to electricity, low incomes and the scarcity of fuels other than paraffin in the local shops. All 21 shops in Zanemvula only sell paraffin. Wood is sold by one private person and gas has to be bought outside the community.

The benefits of solar water heating in terms of vulnerability in this community are many. In terms of climate the level of solar radiation is ideal for a solar water heating project, frost does not occur in the area and overcast weather is not common. The subtropical climate with average winter temperatures around 20 degrees Celsius means that heated water is not a matter of survival but it is greatly appreciated and used for a number of household activities. Water restrictions which might impact the availability of water in the houses have not occurred in the Nelson Mandela Bay Municipality to date (Nelson Mandela Bay Municipality, 2009). The project community is located in an urban setting where electricity connections are the norm. The costs of the SWH are not a matter of concern for these households as the municipality pays for the systems and installation of them. Remoteness and its possible negative effects on the price of solar water heaters is therefore not a factor in the municipal planning and is not a concern of the households.

The need for heated water is only slightly higher in winter months because of the mild climate. The maintenance costs will be covered by the municipality for the first year after the installation. It is not anticipated that these costs will vary with the seasons. Even though the winter months in Port Elizabeth are not particularly cold, the temperature of the water coming from the solar water heater will vary but will always be warmer than the tap water.

The acceptance of the SWH in Zanemvula varied for a number of reasons. Two different companies have been contracted and they are installing two different systems. They work according to the same principle, but look different. According to the beneficiaries the taste of the water differs between the two systems as well. The system which reputedly provides tasteless water is more popular than the 
other. Technical problems like leakages and noise coming from the SWH cause some dissatisfaction as did damage to roof tiles during the installation. Despite these issues the technology is, in general, accepted in the community. The density of the population leads to positive and negative opinions about the SWH spreading rapidly. The government has undertaken to pay for the implementation of SWH's for the group of beneficiaries. Further undertakings at local and national level will influence the availability and costs of such systems. The integration of SWH in government houses is still being debated and a national framework for solar water heating is being developed. Other initiatives are working on carbon finance through registration of projects under the CDM.

As mentioned, there are a number of technical challenges around the SWH that are currently influencing the acceptance and satisfaction of the beneficiaries. There is considerable potential for technological improvement. In terms of shocks the community has not experienced any problems regarding the SWH. Although fires, theft and vandalism have been mentioned as concerns of the beneficiaries none of these shocks have not been reported in the follow-up survey. 'Load shedding' is a strategy used by the state owned electricity supplier Eskom to reduce pressure on the electricity grid by regularly switching off power to different suburbs. The beneficiaries are partly independent of 'load shedding' due to the usage of solar energy for water heating.

\subsection{The Kuyasa CDM Project}

The non-governmental organisation SouthSouthNorth, in cooperation with several consultancies and advisors, designed the first CDM project to be registered on the African continent. Registered in 2005, it was the first project worldwide to be awarded the Gold Standard. The Kuyasa CDM Project is owned by the City of Cape Town. The organization contracted to implement the project is the South African Export Development Fund.

The Kuyasa CDM Project is different from the Zanemvula SWH Project in many ways. The Kuyasa project intervention includes not only the installation of a solar water heater but also the insulation of the roof with ceiling board, repairing the electrical wiring inside the house and the exchange of conventional light bulbs for the more energy efficient compact fluorescent light bulbs (CFL's). All 2 309 households of the original Kuyasa housing project were beneficiaries of these installations. In the period between the design and the implementation Kuyasa expanded, so the project does not cover the whole of Kuyasa as it is today. Because of funding problems, the implementation phase of the project only started in May 2008 and was finalised in March 2010.
Kuyasa is similar to Zanemvula in that it is located on the very outskirts of the city, in this case the City of Cape Town. Kuyasa is part of the greater suburb of Khayelitsha and it can take up to $90 \mathrm{~min}$ utes to travel the 30 kilometers to the central business district by train or mini taxis. Employment opportunities in close proximity are rare and 'even where 'unskilled' jobs do become available, a range of cultural, racial and linguistic factors continue to marginalise Khayelitsha's residents' (Du Toit, 2007). The study by du Toit and Neves revealed that half of the respondents stated that they were unable to speak either Afrikaans or English which is just one of the factors why the authors conclude that Khayelitsha residents remain to a very large measure economically, spatially and racially marginalised from the city (Du Toit, 2007). According to the authors, this is why so many people who migrate from the rural areas of the Eastern Cape into cities like Cape Town 'rarely venture the last 15 or 30 kilometres into the economic hub' (Du Toit, 2007).

According to David Everatt (2009) Khayelitsha had a poverty index of 27.1 in 2006 (poverty index of Motherwell near Zanemvula 16.7 in 2006) which is far above the average of 18.2 in poor urban nodes. Kuyasa, it is suggested by this study, is a much poorer area than Zanemvula. However, it should be taken into account that Zanemvula is a more recent development that is still challenged by the lack of electricity and water. The baseline survey conducted in Kuyasa revealed that the average household is 4 people of which 2.2 are under the age of 18 years. In the whole community of beneficiaries there are 107 people over the age of 60 . Nearly $100 \%$ of the houses are served with water and electricity from the city. The majority of people heat their homes in winter $(63 \%)$ and use paraffin for this $(53 \%)$. Only a few use electricity $(7 \%)$, gas $(1 \%)$ or multiple fuels $(1 \%)$. For the heating of water the electric kettle was the most common appliance $(87 \%)$, followed by an electric stove $(5 \%)$. Multiple fuels are used by a few households $(5 \%)$ and even less use gas $(1 \%)$ or are in the possession of an electric geyser (1\%).

The vulnerability context in relation to solar water heating for Kuyasa is very similar to the one in Zanemvula. Kuyasa differs from the situation in the Eastern Cape in the need for heated water in winter. Winter months get much colder in the Western Cape, increasing the need for warmth. A further difference is the question of maintenance. In Kuyasa it has been decided that households will have to pay monthly fees for this service.

\section{Did the household's capital increase and the vulnerability decrease as a consequence of the installed SWH?}

The findings in the projects show that household capitals have been augmented through the projects 
and particularly through the installation of the solar water heaters. In both projects households' heat water by means other than SWH significantly less frequently and carbon emissions and money are therefore saved. The hot water from the roof is mostly used for bathing and dish washing in both communities. Indoor air quality appears to have improved due to the substitution of fossil fuels with solar energy. Some houses have started heating their homes which they had not been doing before the project. This might have a negative effect on the indoor air quality, but may still improve health and comfort. Both projects appear to have performed equally regarding the stimulation of natural capital.

Natural capital has further been affected by changes in heating, cooking and lighting fuels in the Zanemvula community. This change was mainly caused by the general electrification of the houses. The fuel situation in Kuyasa suggests that changes in fuel use are rather slow and difficult to stimulate by installations like SWH and ceilings. Use of wood as an energy source seems to have disappeared altogether. The survey found no support for the expectation that electricity savings due to the use of SWH motivate households to use electricity for more household purposes and use paraffin less.

Social capital is being addressed in Zanemvula by improving knowledge and understanding of the people living in the community. Many community leaders worked as enumerators and conducted interviews with the people in their area and beyond. The community education workshop and temporary employment opportunities brought people closer together. There was no evidence of conflict between beneficiaries and non-beneficiaries in the survey. At Kuyasa, intensive communication and participation with the residents created understanding. It is likely that in Zanemvula more communication would have been useful in order to answer all the questions around the selection of beneficiaries for the project and ensure greater willingness to cooperate with the project. This has not always been the case as a toyi-toyi ${ }^{5}$ in the beginning of the project showed. The Kuyasa project is also far ahead of the Zanemvula project when it comes to creating a stimulating and open atmosphere. By training one member of each household, thus transferring employment and skills to many people in Kuyasa, the CDM Project managed to gather momentum for establishing entrepreneurial initiatives. The next years will show if and how this momentum is being used. Training and employment in Zanemvula was temporary, on a much lower level and failed to provide the enabling and motivating effect.

Human capital was stimulated in both projects with success but, again, with emphasis on different levels. Zanemvula provided on-job training for eight local employees; Kuyasa enrolled its team of 85 people in different colleges and accredited courses. The duration of employment in Zanemvula was for some weeks, Kuyasa employed for the whole period of implementation which will be over 33 months. The transfer of information about renewable energy and climate change has been taken more seriously in Kuyasa - a training DVD was produced and training sessions on these issues were run several times. In Zanemvula a three day workshop and a planned brochure were used to try to achieve the same objective. Physical health and psychological wellbeing seems to have improved in Kuyasa more markedly than in Zanemvula, however, this is not a completely fair comparison because the insulated ceiling installation contributed a lot to that success. When it comes to the perception and opinion of the solar water heater systems, both projects reported that lives had been made easier through savings in time and money.

Physical capital involved the ownership of the solar water heating technology in both projects. The technology is paid for by the projects in both cases and maintenance is ensured for the first few months. Kuyasa has set up its maintenance plan already and is planning to collect R30 per month from each household. The municipality in Port Elizabeth is still considering the way forward on this matter. Additional income has definitely been generated in greater volumes in Kuyasa than in Zanemvula where employment was on a much smaller scale.

Financial capital is again linked to differences in the scale and duration of employment, being greater in Kuyasa than in Zanemvula. The expenditure savings are higher in the Kuyasa project too, where three energy saving interventions have been installed. The electricity saving data from Kuyasa shows the potential of the solar water heater to contribute positively to the households' budget, but the increased water expenditure could be seen as a negative. There was a balance of about R63 savings per winter month. The lack of valid expenditure data and the lack of a suitable baseline in Zanemvula prevent any comparison. Calculated expenditure savings are influenced by prices of paraffin (which are recalculated and adjusted by government every month), LPG and electricity. Paraffin and LPG prices were correlated throughout the year, except for the months of January and February when the paraffin price was inflated. Electricity prices are dependent on the municipalities; the price for electricity rose for both communities in the last year. ${ }^{6}$ Cousins and Mahote (2003) found in their pre-installation assessment in Kuyasa that monetary savings generally 'help to alleviate strain placed on various types of social networks' through allowing them 'more leeway in the choices they make on a daily basis in deciding where and how they spend or invest money and allows them 
to remain sensitive to subtle changes in the relationships in these networks' (Cousins, 2003).

Gender capital has been researched in more detail in the Zanemvula project and indicates that women and men benefit in different ways from solar water heating. Women, who are mainly responsible for tasks in the home, enjoy the constant availability of heated water which saves them time and effort during the day and allows them to sleep longer in the mornings. Men's personal hygiene has improved due to the new service of hot water and, additionally, time is saved because they are independent of female efforts to prepare a bath. It was observed in Kuyasa that the women are more informed about the changes caused by the SWH in their households which suggests that these changes affect their lives more significantly than men's.

To date, the benefits of solar water heating have been assumed, based on theory and literature around energy and poverty. These assumptions have here been shown to be correct in most of the cases. A switch in fuels used for cooking and heating from paraffin to electricity has not been observed. The introduction of electricity has had a great impact on the choice of energy used for household purposes, but the solar water heater and its accompanied expenditure savings has not. This shows that other needs have a higher priority and that negative effects of paraffin use are not perceived as being as pressing as other things the saved money could be allocated towards. The effect on the wellbeing of the households, particular on the women was impressive, despite being expected. The ongoing research project around mental health in Kuyasa seems likely to reveal important results. This paper has researched two very different approaches to participation, training and employment of people from the communities when implementing a SWH intervention. Without doubt, the Kuyasa CDM Project has set a great example for the successful integration of a project into a low-income community.

The vulnerability of the benefiting households in the Zanemvula SWH Project and the Kuyasa CDM Project has been reduced as a consequence of the installation of solar water heaters. The assumed linkages between solar water heating and vulnerability presented at the beginning of each case study have proven to be sound. Many linkages between the vulnerability of the households and the installation of SWH either caused positive, vulnerability reducing, change or no change. SWHs do not increase the vulnerability of the studied households. Issues concerning costs related to the $\mathrm{SWH}$ were not applicable as everything was paid for by the projects. Long-term maintenance is the only issue which could put an extra strain on the households' budgets or reduce the achieved savings through reduced electricity consumption. In both projects households are independent from grid electricity for their hot water needs and the technology is generally accepted in the communities. Shocks like theft or vandalism have not occurred so far and even seasonality does only have a small impact on the temperature of the water in the SWH.

\subsection{Discussion and recommendations}

The two case study projects presented differ considerably in the way they were planned and implemented in many ways. The project in Zanemvula was designed and implemented by the engineers working in the electricity and energy department of the municipality of Port Elizabeth. Their learning curve has been steep in the 12 months from the initial planning to the first installations of $\mathrm{SWH}$. 'Before we started this project the general feeling from the engineers was just to enter the area, install the systems and then get out' (Merwe, 2009). Throughout the implementation of the SWH project it become increasingly obvious to the management that 'the biggest issue surrounding the poorer communities is not the provision of extra services, but the education of the communities to sustain these projects themselves' (van der Merwe, 2009). The subsequent community workshop and establishment of the 'maintenance and complaints office' in the community were first steps towards creating more ownership of the project in the community.

The Kuyasa CDM Project on the other hand was designed by a non-governmental organisation that planned for five years before the project commenced. The community was kept informed about the plans from the start and even though not always conducted in a proper participatory manner the community was always involved in some way. This was quite different from the situation in Zanemvula where technicians sometimes installed a SWH on the roof of surprised households. In Kuyasa people waited in anticipation for the project to start. In fact, the site office manager Ndamane was put under a lot of pressure by the residents of Kuyasa, especially in winter months when people were desperate for warmth and warm water in their houses (Ndamane, 2009). The situation in the two projects was thus very different in terms of local ownership and participation of the beneficiaries from the start. These differences continued to affect the projects throughout their implementation.

The perception of the houses having a solar water heater is of high relevance when it comes to the social acceptance of the technology. Acceptance can be defined as Roger does as the 'use, or adoption of a technology versus just the passive approval of a technology, or intention to use it' (Mallett, 2007). The acceptance and use of the technology is crucial not only for ensuring the success if the ongoing mass-roll out of solar water heaters, but also for the carbon finance aspect of such projects. 
The reduction of greenhouse gas emissions through solar water heating is based on the assumption that solar energy is substituted for fossil fuels for the heating of water. This might appear self evident, but behavioural change is required by the households. Site office manager Ndamane commented on this issue that some people in the project are still busy adjusting to the new service coming from the roof. Occasional reminders that the heated water from the SWH can be used for all types of household purposes are still needed (Ndamane, 2009). In the survey results however, there was not a single house that stated that it would not use the water provided by the SWH at all. The data does, on the other hand, show that the majority of respondents in the Kuyasa CDM Project perceive their electricity consumption as being on the same level as before. This conflicts with the expenditure data, which shows a reduction in electricity and fuel expenditure, but indicates that people might still be using the same amount of electricity by increasing usage for purposes other than heating water. The municipality in Port Elizabeth is currently looking into this issue through monitoring the electricity consumption of individual households and comparing these numbers with the perceived changes in consumption by the household members.

Resulting out of this research, the following issues around information, participation, education and follow-up have been identified as key for the sustainability and smooth implementation of such projects. These recommendations assume that the project management is not following a participatory planning process in order to identify the type of change the community might wish for, but a conservative top-down approach in which the project is largely designed without the participation of members of the community.

- Information: actively engage with the local councillor, community liaison people and community leaders (hereafter referred to as VIPs) about the project as soon as possible; consult VIPs on who should receive the technology if the project can only include a limited number of people; make the project known as soon as it is clear that it will happen.

- Participation: plan the implementation phase in collaboration with VIPs; take seriously advice on who to include and what processes to follow; ensure the transfer of technical skills to members of the community; set up a maintenance system which makes use of the locally accumulated skill; consult VIPs with anything related to employment of members of the community.

- Education: discuss the advantages and disadvantages of the technology openly with the members of the community in order to allow them to make an informed choice about the par- ticipation in the project; train the households on the correct usage of the technology in order to reduce maintenance calls; explain the context of the project (climate change, renewable energies, energy efficiency, etc) to allow households to speak in an informed way about the project and feel part of a movement which extends beyond the boundaries of their community; spread this knowledge also to less likely target groups of the community - for example, engaging with the local schools to educate learners about solar water heating.

- Follow up: ensure suppliers stay committed to the project as long as they are needed (special financial arrangement or conditions in contract can support this); engage with VIPs on regular basis about the project; react to issues raised by VIPs regarding the project (Wlokas, 2011).

\section{Conclusion}

This paper explored the assumption that solar water heaters installed on low-income households make a social contribution by increasing their households' capital and decreasing the vulnerability. The Sustainable Urban Livelihood Model, with the addition of gender capital to the household capitals, was chosen for the analysis. Results from household questionnaire surveys and complementary qualitative information from two case study projects in South Africa showed that the installed renewable energy technology caused multiple changes in lowincome households.

It was found that solar water heaters contribute positively to the alleviation of energy poverty through providing a constant source of heated water. The extent to which this technology is contributing is, however, dependant on the approach and strategies used by the project implementer. The excellent international reputation of the Kuyasa CDM Project was confirmed on the basis of empirical data. Comparison of the Kuyasa project with the Zanemvula SWH Project revealed common benefits of solar water heater installation.

Less frequent heating of water was identified as the main change for natural capital. Further changes in the use of energy in the household could not be linked to the SWH installation. Improved physical health, increased wellbeing through a more comfortable life and time saved, transferred knowledge and skills around solar water heating and additional employment are major contributions to human capital. Social capital was stimulated through additional and intensified connections between people in the communities which is mainly due to the shared experience of working and learning together and getting to know each other better through the household surveys that were conducted. Physical capital is increased by the fact that the households own the new SWH technology 
and additional material wealth is a possible consequence of employment created by the projects. The savings of energy costs; new, reliable, although temporary income sources for the people employed by the projects; the absorption of costs for the technology, its installation by the governmental bodies and initial financial support for maintenance are positive changes related to the financial capital of households. In terms of gender capital, time and stress savings for women and improved personal hygiene for men have been identified as the main benefits.

Despite the many benefits common to both case studies, a major conclusion of this study is that engaging communities and encouraging their active involvement is crucial to realising the full benefits of the installation of SWHs in low-income households. Households have to be informed and constantly updated about plans concerning their lives. Educational preparation is necessary to empower people to use the new technology as efficiently as possible to meet their needs. Participatory planning of the installation process and maintenance plan is essential for a long-term success of the project. Gender conscious planning and implementation should be mainstreamed throughout the various project phases. Only if these recommendations are followed will the assumption by the South African government that the mass rollout of solar water heaters will contribute to the alleviation of poverty be justifiable.

\section{Notes}

1. Dance used in Southern Africa to express (political) protest.

2. Foreigners living in low-income settlements in South Africa have become targets of xenophobic violence since May and June 2009.

3. The study is based on the poverty matrix recommended by South Africa and makes use of official Census data from 1996, 2001 and independent survey data from 2006 . The index includes data on education, unemployment, dwelling type, household composition, household expenditure, household size, water, refuse removal, sanitation, electricity and telephone.

4. So-called illegal connections to neighbours or self made electricity connections from street lights etc are common in areas which have not been electrified and households which cannot afford the once of connection.

5. Toyi-toyi: dance which become famous particularly during Apartheid in South Africa for political protest.

6. Nelson Mandela Bay Municipality in Port Elizabeth increased their price for pre-paid meter customers from $49.075 \mathrm{c} / \mathrm{kWh}$ to $61.344 \mathrm{c} / \mathrm{kWh}$ in July 2009 and the City of Cape Town raised the price for lowconsumption customers from $0,489 \mathrm{c} / \mathrm{kWh}$ to 0.504
c/kWh (Nelson Mandela Bay Municipality, 2009) (City of Cape Town, 2009).

\section{References}

Afrane-Okese, Y. (2009). Draft Strategic Framework \& Implementation Plan For South African National Solar Water Heating, Overall Recommended High Level Strategic Framework, presented at the National Solar Water Heating Conference. 'Building Consensus on Accelerating the Rollout of Solar Water Heaters in South Africa . Johannesburg, South Africa.

Barnett, A. (2001) Looking at household energy provision in a new way: The Sustainable Livelihoods approach. Boiling Point, 46.

Batidzirai, B. L. (2009). Potential for solar water heating in Zimbabwe. Renewables and Sustainable Energy Reviews , 567-582.

Bekker, B. E. (2008). South Africa's rapid electrification programme: Policy, institutional, planning, financing and technical innovations. Energy Policy , 31153127.

Cawood, W. S. (2004). The application of solar water heaters in low-income housing.

Chambers, R. (1989) Vulnerability, coping and policy, IDS Bulletin, 20 (2), 1-7.

City of Cape Town. (2009). The City's new electricity tariffs, Consumer Hand out. City of Cape Town.

Cousins, T. \&. (2003). Social Research for Kuyasa Pilot CDM Project Activity, Assessment of the impact of energy efficiency interventions in a low-income housing settlement Kuyasa Khayelitsha. Cape Town.

Department of Minerals and Energy. (2009). Solar energy. Retrieved 11 23, 2009, from www.dme.gov.za/ energy/renew solar.stm.

DOE, (2011, March ). SWH's in low-income households. (H. L. Wlokas, Interviewer).

Du Toit, A. N. (2007). In search of South Africa's Second Economy: Chronic poverty, economic marginalisation and adverse incorporation in Mt Frere and Khayelitsha, CPRC Working Paper 102. Chronic Poverty Research Centre.

Han, J. M. (2010). Solar water heaters in China: A new day dawning. Energy Policy, 383-391.

Kuyasa, P. (2005). Clean Development Mechanism Small-Scale Project Design Document (CDM-SSCPDD), Kuyasa low-cost urban housing energy upgrade project, Khayelitsha (Cape Town; South Africa), Version 14a.

Mallett, A. (2007). Social acceptance of renewable energy innovations: The role of technology cooperation in urban Mexico. Energy Policy, 2790-2798.

Manyaapelo, K. (2000). Consumer response to mobile solar water heating in the low-income sector, South Africa. Boiling Point 45 , 34-36.

Mokwena, L. (2009). Municipal Responses to Climate Change in South Africa, The case of eThekwini, the City of Cape Town, and the City of Johannesburg.

Ndamane, Z. (2009, 12 18). Personal communication Site Office Manager of Kuyasa CDM Project . (H. L. Wlokas, Interviewer).

Nelson Mandela Bay Municipality. (2009). Electricity 
Tariffs as from 1 July 2009, municipality documentation.

Peters, D. (2009). Speech at the National Solar Water Heating Conference 'Building Consensus on Accelerating the Rollout of Solar Water Heaters in South Africa'. Johannesburg, South Africa.

REN21 Renewable Energy Policy Network. (2005). 'Energy for Development: The Potential Role of Renewable Energy in Meeting the Millennium Development Goals. Washington, DC: Worldwatch Institute.

Smit, G. (2009). Zanemvula social survey qualitative report. Cape Town.

Stats SA. (2008). General Household Survey 2007, P 0318. Retrieved 12 07, 2009, from www.statssa.gov. za/publications/statsdownload.asp?PPN $=$ P0318.1\&S $\mathrm{CH}=4436$

Stats SA. (2009). Quarterly Labour Force Survey, Quarter 3, 2009. Retrieved 12 21, 2009, from www. statssa.gov.za/PublicationsHTML/P02113rdQuarter2 009/html/P02113rdQuarter2009.html.

Tunisia, P. (2009). Clean Development Mechanism Small-Scale Project Design Document (CDM-SSCPDD), Solar Water Heater Programme in Tunisia, Version 02.

UNDP. (2009). Human Development Report 2009 - HDI rankings. Retrieved 12 07, 2009, from http://hdr.undp.org/en/statistics/.

Van der Merwe, S. (2009). Lessons learned by EE project manager. Most Significant Change Story . Port Elizabeth.

Van der Merwe, S. (2009). Low Pressure Solar Water Heating Pilot Project for Low Cost Housing, Project intern document. Port Elizabeth: Nelson Mandela Bay Municipality.

Vietnam, P. (2009). Clean Development Mechanism Small-Scale Programme of Activities Design Document Form (CDM-SSC-PoA-DD), Installing Solar Water Heating Systems in the South of Viet Nam, Version 01.

Visagie, E. (2008). The supply of clean energy services to the urban and peri-urban poor in South Africa. Energy for Sustainable Development , 14-21.

Winkler, H. T. (2002). Baselines for Suppressed Demand: CDM Projects Contribution to Poverty Alleviation. South African Journal of Economic and Management Sciences , 413-429.

Wlokas, H. L. (2011). What can solar water heating contribute to the livelihoods of low-income households? Domestic Use of Energy Conference. Cape Town.

Received 30 March 2011; revised 12 May 2011 